\title{
BOEKBESPREKING.
}

Prof. Dr. H. van Oyen: Christelijke Ethica. N. V. Servire, Den

Haag.

Hoewel, uit die aard van die serie waarin dit verskyn, sketsmatig, is hierdie werk iets besonders in uitgangspunt en behandeling. Dit is 'n prinsipiële rekenskap oor die Christelike Etiek. Eerstens kom onder die soeklig die vraag of die Christelike Etiek christelik moet wees. Dit klink snaaks maar hierdie vraag was lank 'n strydpunt in die Teologie. Anders gestel lui dit: Kan daar so 'n wetenskap as Christelike Etiek bestaan? Prof. W. J. Aalders, die eminente ethicus van Nederland, het konsekwent volgehou dat die Etiek as wetenskap, hom net kan betrek op die menslike verhoudinge in die tyd; die bestaan van 'n aparte etiek, 'n christelike, is dus nie te regverdig nie. Sonder wyfeling neem Prof. van Oyen hierteenoor stelling in. Sy uitgangspunt is: "Christelijke Ethica is een onderdeel van de Theologie."

Natuurlik is Christelike Etiek ook vroeër beoefen, maar daar was oorwegend die neiging om die hele sisteem van behandeling te ontleen aan Aristoteles met die gevolg dat die grondslae en uitgangspunt van die wetenskap op allerlei terreine gesoek is behalwe in die Teologie. Hierin het daar in die afgelope jare wel kentering gekom. Etlike geleerdes, o.a. A. D. Muller en A. de Quervain, het tot die uitgangspunt van hul behandeling gemaak, die Locus de Deo. Dit doen ook die outeur van hierdie werk; hy gaan uit van die reformatoriese opvatting aangaande God. Daarom staan hy ook veroordelend teenoor die standpunt van die Moderne Protestantse Etiek, die skool van Brunner en Gogarten. Tereg noem hy die laat geld van die s.g. skeppings-ordeninge, waarop die beskouinge van hierdie skool gegrond is, 'n terugkeer tot die leges naturae (die natuurreg) van die Rooms Katolieke Kerk.

Vir die Christelike Etiek is God's wil die sedelike en voorwerp daarvan is die "nuwe mens"; hierin is geen plek vir die "Du sollst" van Kant nie. Uiteindelike doelstelling van die Christelike Etiek is die Koninkryk van God; onder hierdie gesigspunt vloei wil van God, Wet en Evangelie saam.

21) Proclamations from 1900-1902, p. 198-199. 
Die derde afdeling van hierdie werkie gaan oor "Die Heiliging”. As norm van die christelik etiese aanvaar die skrywer die uitsprake van die Bybel oor die verhouding van die mens tot God en sy naaste. Hoe die afsonderlike gebooie van die Dekaloog verstaan en nageleef moet word, verneem ons uit die woorde van Jesus uit die Bergrede. Die eis van die liefde is hierin leidend en bindend. As terreine vir die aanwending van hierdie beginsels sien die outeur die verhouding van die mens tot God en sy naaste. Hoe die afsonderlike gebooie van die Dekaloog verstaan en nageleef moet word, verneem ons uit die woorde van Jesus uit die Bergrede. Die eis van die liefde is hierin leidend en bindend. As terreine vir die aanwending van hierdie beginsels sien die outeur die verhouding van die staat teenoor die state er. van die indiwidu teenoor die staat, en sy houding in die gesin en huweliksverband. Ook onder hierdie laaste behandeling word telkens prinsipiële sake bespreek: reg en sedelikheid, leuen en waarheid en eindelik, Kruisdragen en volharden.

Omvattend is die boekie met sy 128 bladsye nie; prinsipiëel en aktueel is dit sekerlik. As $n$ inleiding tot die studiegebied van die Christelike Etiek is dit voortreflik.

\section{A. S. GEYSER.}

H. L. Gonis, Latynse Grammatika en Leesboek. Derde en Vierde Jaargange. Voortrekkerpers Bpk., Johannesburg. 1947.

Met hierdie uitgaaf is die grammatika-kursus van die hand van Prof. Gonin voltooi. Vir die onderwys in ons land is dit van groot belang. Aan die opstel van 'n handboek is nogal eise verbonde wat mens so op die oog-af nie dadelik besef nie. Die leerinhoud is natuurlik die hoofskotel, maar net so aktueel is die wyse waarop die leerinhoud opgedis word. Om dit eenvoudig in die volgorde van die taallogika weer te gee, was miskien nog in die vorige eeu gangbaar maar die gespesialiseerde onderwysmetodes eis hedendaags iets anders. Die uiteensetting moet nie net sover moontlik volledig wees nie. dit moet nie net die regte verhouding ken van wat belangrik en minder belangrik is nie; heldẹheid en goed-verantwoorde stelling moet gepaard gaan met $n$ rake waarneming van die psigologiese spanning tussen die dosent en die student. Dit is alleen bereikbaar wanneer die onderwyser hom tenvolle kan verplaas in die posisie van die leerling. Ook vir die opsteller van 'n handboek geld die humanitêre waarde van die woorde: Wat jy nie wil hê dat andere aan jou moet doen nie..."

$\mathrm{Ek}$ ken min handboeke in die Europese literatuur wat volledig aan hierdie eise voldoen; in ons Afrikaanse onderwys-literatuur is dit na verhouding nog skaarser. As voorbeeld van die weldeurdagte doelgerigte sisteem van onderwys, is hierdie serie werke van die hand van Prof. Gonin uniek en allesins navolgenswaardig. Vir die bevrediging van eie nuuskierigheid het ek dadelik deurgeblaai na die bespreking 
van "n paar van die voetangels in die latynse grammatika -- die gerundium en die gerundivum, konstruksies met die supinum en indirekte vrae en dit was in lonende eksperiment. Die skrywer ontrafel kortliks en in eenvoudige taal die wording van die konstruksie en helder dir op met enkele omskrywinge. Mens ken na 'n dergelike behandeling nie net dié uitlopers van die latynse taal-eie nie, mens verstaan dit.

Naas sy twee voorgangers neem hierdie werk in ereplek in om te voorsien in 'n langbestaande leemte in ons onderwys. Uit die oorfuiging van die waarde van hierdie werk waag ek my aan n paar suggesties: Sou dit nie wenslik wees om, met die oog op die eenvormige onderrig in ons land, hierdie reeks in Engels te vertaal nie? Sou die skrywer en die uitgewers nie ook in 'n verdere behoefte kan voorsien nie - nl. $n$ bondige inleiding tot die latynse letterkunde nie? Die belangstelling vir ' $\mathrm{n}$ taal ontplooi eers tenvolle by nadere kennismaking met die hele gebied van daardie letterkunde.

Die boek is, soos sy voorgangers, in ' $n$ handige formaat met in sterk omslag gebind. Drukfoute wat hier en daar voorkom, bv. op bls. 118 lees ;, helfte" vir ",helfde", sal ongetwyfeld by eventuele herdrukke uitgeskakel word.

\section{A. S. GEYSER.}

Inleiding tot de Theologische Studie, samengesteld door de Faculteit der Godgeleerdheid aan de Rijksuniversiteit te Groningen, onder redactie van Prof. Dr. H. van Oyen. J. B. Wolters. Uitgeversmaatschappij. N.V. Groningen-Batavia 1946. Prys ongeveer 14/-. Hierdie werk gee op omtrent 250 bladsye $n$ oorsig van die verskillende studieterreine wat deur die teologie op die staatsuniversiteite in Nederland bestryk word. Dis veral bedoel vir beginnende studente. wat by hul aankoms aan die universiteit nog nie in staat is om die geheel van die vakke te oorsien nie en sekerlik baie dankbaar sal wees om deur die skrywers van hierdie gids touwys gemaak te word.

Maar soos dit maar gewoonlik gaan is ' $n$ inleiding tot die teologie netso interessant, miskien nog interessanter, vir dié wat hul teologiese studies al voltooi het. Hulle kan die boek met meer insig lees en sal al lesende tot die gevolgtrekking kom dat teologiese studie 'n ding is wat nooit voltooi is nie. Hierdie boek toon die leser hoe baie daar is waar hy nog nooit voldoende aandag aan gegee het nie en dit wek hom op om altans in deel van wat hy versuim het nog in te haal.

Die indeling van hierdie ensiklopedie sal menig leser verwonder. Dit word bv. nie duidelik nie, hoekom die Biblica nie onder die ..Bijbelsch gedeelte" verskyn nie, maar onder die "Systematisch gedeelte" en dan nog wel as laaste vak, na o.a. die dogmatiek en die wysbegeerte van die religie. Dit moet amper die indruk wek as sou die biblica van daardie vakke afhanklik wees, wat elke beoefenaar van die Biblica ongetwyfeld sal ontken en ook deur die bladsye wat an hierdie vak 
in hierdie werk gewy word nie gesuggereer word nie. In die sinnetjie wat die betrokke skrywer, die hoogleraar J. H. Semmelink, aan die plek van sy vak wy: ,In dit werk is zij ( $\mathrm{nm}$. die Biblica) door den inleider ook bij de systematische vakken gegroepeerd" - in daardie meedeling meen ons te hoor dat Semmelink persoonlik nie met die indeling van Van Oyen saamstem nie. Waarskynlik het ons hier invloed van Van der Leeuw, wat op die voetspoor van Doedes en Baljon in sy "Inleiding tot de Theologie" die Biblica onder die "dogmatische theologie" reken.

Netso verwonderlik is dit, dat die Phaenomenologie van die godsdiens en die Simboliek nie onder die historiese. maar onder die sistematiese gedeelte gerangskik is. Dit lyk amper of die samesteller die gedagte huldig as sou historie hom net met die verlede besig hou. Dis $n$ miskenning van die gebruik van hierdie term alreeds van die klassieke tye af. Die gewone opvatting is dat die historiese deel van die teologie hom besig hou met wat is, die sistematiese met wat behoort te wees, m.a.w. die historiese teologie is descriptief, die sistematiese normatief. Dit word nie duidelik hoekom hierdie boek van hierdie algemeen aanvaarde onderskeiding afsien nie.

Die sistematiese gedeelte het sodoende 'n onnatuurlike swelling ondergaan, wat nog vermeerder word deur die anomalie dat die Liturgiek twee maal voorkom, sowel onder die sistematiese as onder die praktiese gedeelte. Ook deur die sin in die "woord vooraf": „In verband met de eigen plaats door den auteur op dit terrein ingenomen. alsook met het oog op de speciale colleges, door prof. v. d. Leeuw steeds over Liturgiek gegeven, zal de gebruiker van dezen bunde! zoowel van hem als van prof. Semmelink. een onder ander gezichtspunt geschreven bijdrage over dit vak aantreffen" - ook deur hierdie sin word $n$ dergelike doublure en verwarring nie geregvaardig nie.

Die gevolg is nou. dat die "Bijbelsch gedeelte". 73 bladsye omvat, die „Historisch gedeelte" 34, die .,Systematisch gedeelte" 92, die "Practisch gedeelte" 35 . Hierdie getalle-verhouding bied geen suiwer beeld van die studie aan $\mathrm{n}$ reformatoriese fakulteit van teologie nie.

Wat die inhoud van die boek betref, die meeste van die sketse oor die verskillende vakke lees mens met genoeë. Dis oriënterend en verhelderend. Hier en daar is nog 'n sekere eensydigheid in die gesiteerde literatuur; die Duitse invloed op die Nederlandse teologiese studie is blykbaar nog altyd oorwegend. S Soms word, terwyl Duitse literatuur sonder verdere byvoeging gesiteer word, agter Engelse publikasies die (waarskuwing of aanbeveling?) "Engelsch" geplaas. Die werke van Cook, Oesterley en Robinson vind by die behandeling van die Ou Testamentiese studie geen vermelding nie, netsomin as die besonne en nuttige Franse werke van Barrois en Ricciotti.

Die mooiste skets, met die meeste geesdrif geskryf, is na die mening van die resensent dié wat Prof. Lindeboom gee oor Kerk- en 
Dogmengeskiedenis. Die skrywer beskik oor 'n jeugdig entoesiasme en 'n styl wat daardie entoesiasme op jeugdiges kan oordra.

Enige leser sal dit met die samesteller betreur dat Prof. v. d. Leeuw as in gevolg van sy drukke werksaamhede as minister nie in staat was om in sy bydrages meer te gee as net ' $n$ paar hooflyne. Fakulteit en studente, so gaan hy deur, sien 'n rede tot groot blydskap in die feit dat Sy Eksellensie nogtans as lid van die fakulteit aanwesig is in hierdie bundel. Ons verstaan die blydskap, ons het sy kort bydraes ook met dieselfde dankbaarheid en bewondering gelees as sy vroeëre publikasies op die gebied van die godsdienswetenskap, Maar tog sou dit vir die harmoniese opbou van die boek as n geheel en vir die informasie van die leser op die gebied van die godsdiensgeschiedenis en aanverwante vakke beter gewees het as meer uitvoerige opstelle oor hierdie vakke van 'n ander hand verskyn sou het. Die bedoeling van die boek is tog nie in die eerste plek om die Groningse fakulteit te presenteer nie, maar om die leser te help.

'n Vreemde lapsus kan mens vind op p. 18-19, waar die Midrasjliteratuur tot die Aramese taalgebied gereken word. Verwondering baar ook die feit dat op p. 165 Breasted's Dawn of conscience onder die literatuur oor die gewete genoem word.

Die Nederlands van die verskillende lede van die fakulteit variëer sterk. Dis 'n bietjie verontrustend dat waar die ouere lede oor die algemeen korrek, enkele selfs bewonderenswaardig mooi Hollands gebruik, die jongere menigmaal teen die gees van die taal sondig. Dit lyk of die kennis van die Nederlandse taal die laaste tientalle jare sterk verminder.

Tereg breek p. 172 die staf oor studente wat in die mening verkeer „dat zij hun Grieksch en Latijn tot op hun eindeksamen in hun leven moeten meeslepen, om het dan voor goed vaarwel te zeggen". Maar wat moet dan gesê word van hybridiese woordvormings soos „monolateraal" (p. 46) en „O. Testamentolatrisch" (p. 75) en a fortiori van "heroi eponymoi" (p. 33)? Oor die algemeen kom daar baie foute in die klassieke sitate voor.

Aan die nut van hierdie boek doen hierdie klein vlekke gelukkig maar min af. Met die gemaakte voorbehoude ag ons dit 'n geskikte hulpmiddel vir ons studente en 'n nuttige naprediker vir ons afgestudeerde teoloë.

\section{A. VAN SELMS.}

M. Buber, Moses. East and West Library, Oxford $\mathcal{E}$ London, 1946 (in werklikheid 1947). Prys 12/6.

Hierdie monografie is deur I. M. Lask in 'n vloeiende en aangenaam leesbare Engels vertaal. Dis onnodig om die outeur aan die publiek voor te stel; sy boeke oor die Chassidisme, sy vertaling, in samewerking met Rosenzweig, van die Ou Testament, sy „Königtum 
Gottes" het die voormalige opperrabbyn van Berlyn, nou hoogleraar aan die universiteit van Jerusalem, oor die hele wêreld bekend gemaak.

In die boek wat ons hier ankondig gee die skrywer op ruim 200 bladsye sy beeld van Moses. Dit kan natuurlik nooit iets anders wees as sy beeld van Moses nie; die persoonlike waardering van feite en beskouing van bronne speel by 'n studie soos hierdie een onvermydelik 'n oorheersende rol. Mens kan dan ook nie meer eis van die ",biograaf" van Moses nie as dat hy in sy metode konsekwent bly en geen belangrike elemente uit sy bronne verwaarloos nie. Aan daardie eise voldoen hierdie wèrk seker wel.

Dit is origens merkwaardig om te sien hoe hierdie oud-rabbyn noukeurig dieselfde metode van ondersoek volg as die liberaalprotestantse geleerdes van die vorige en hierdie eeu. Die resensent het veral daarom begerig na hierdie boek gegryp omdat hy verwag het dat die outeur ook op die een of andere manier gebruik sou gemaak het van die tallose legendes oor Moses wat in die Aggada gevind kan word. Maar hulle word selfs nie vermeld nie. Die enige bron wat die skrywer gebruik is die O.T. Nie sonder verwondering lees die nie-Jood die beskouings van hierdie rabbyn oor die legendariese elemente in die geskiedenis van Moses. in Groot deel van die Bybelse berigte word as sage en legende beskou, en die historiese kern daarvan blyk onder die hande van die outeur partymaal uitermate klein.

Die stelligheid, waarmee bepaalde berigte as legendaries bestem. pel word lok by die leser teenspraak uit. Dit sou egter 'n hele boek verg om teenoor die posisie wat Buber inneem in andere voorstelling van sake te stel; ' $n$ norm waaraan ons die relatiewe waarde van die verskillende Moses-beelde kan toets het ons feitlik nie. Uiteindelik berus, gesien die skaarsheid en eensydigheid van ons bronne, iedere Mosesbeeld op persoonlike voorkeur en geloof. Dit sou moontlik wees om 'n geskiedenis van die Moses-voorstelling te skrywe wat in menige opsig 'n parallel sou wees van Schweitzer se Geschichte der LebenJesu-Forschung. Daar bestaan in rasionalistiese (Colenso), 'n roman.tiese (De Vigny), in kwasie-naturalistiese (Freud) en nog menig ander Mosesbeeld Soos. reeds aangedui is die Moses-beeld van Buber dié van 'n gematigde liberale protestant. Nuwe gegevens bied dit uiteraard nie. Die Keniete-hipotese word nadruklik verwerp, die identiteit van Moses se God met die God van die vaders sterk beklemtoon. Daarvoor is dit nie nodig om Jood te wees nie.

Om saam te vat: hierdie boek is so westers, dat dit vir 'n westerling ' $n$ bietjie teleurstellend is. Niettemin verdien dit aandag as 'n goedgeformuleerde poging tot rekonstruksie van die beeld van Moses.

A. VAN SELMS. 